\title{
Synthesis and Characterization of $\mathrm{CuIn}_{2 n+1} \mathrm{~S}_{3 n+2}$ (with $\mathrm{n}=0,1,2,3$ and 5) Powders
}

\author{
Naoufel Khemiri*, Dhafer Abdelkader, Bilel Khalfallah, Mounir Kanzari \\ Photovoltaic and Semiconductor Materials Laboratory, Tunis-El Manar University, Tunis, Tunisia \\ Email: ${ }^{*}$ naoufel_khemiri@yahoo.fr
}

Received November 25, 2012; revised December 28, 2012; accepted January 5, 2013

\begin{abstract}
$\mathrm{CuIn}_{2 \mathrm{n}+1} \mathrm{~S}_{3 \mathrm{n}+2}$ crystals were synthesized by horizontal Bridgman method using high purity copper, indium, sulfur elements. The phases and crystallographic structure of the $\mathrm{CuIn}_{2 n+1} \mathrm{~S}_{3 \mathrm{n}+2}$ crystals were analyzed by X-ray diffraction (XRD) and the composition of the material powders was determined using the energy dispersive X-ray analysis (EDX). Measurement data revealed that $\mathrm{CuIn}_{2 \mathrm{n}+1} \mathrm{~S}_{3 \mathrm{n}+2}$ materials have not the same structure. In fact, $\mathrm{CuInS}_{2}$ and $\mathrm{CuIn}_{3} \mathrm{~S}_{5}$ crystallize in the chalcopyrite structure whereas $\mathrm{CuIn}_{5} \mathrm{~S}_{8}, \mathrm{CuIn}_{7} \mathrm{~S}_{11}$ and $\mathrm{CuIn}_{11} \mathrm{~S}_{17}$ crystallize in the cubic spinel structure.
\end{abstract}

Keywords: $\mathrm{CuIn}_{2 \mathrm{n}+1} \mathrm{~S}_{3 \mathrm{n}+2}$; Synthesis; Structural Properties

\section{Introduction}

Developments of thin film solar cells based on $\mathrm{CuInS}_{2}$ and related alloys have made considerable progress in recent years. Copper indium sulfide thin films are one of the most promising absorber materials in solar cells because he has a high optical absorption coefficient $\left(10^{5}\right.$ $\mathrm{cm}^{-1}$ ), and an optical band gap of $1.5 \mathrm{eV}$ [1] and that's why $\mathrm{CuIn}_{2 \mathrm{n}+1} \mathrm{~S}_{3 \mathrm{n}+2}$ materials attract much attention. In addition, the materials do not contain any toxic elements such as $\mathrm{Ga}$ or Se, and this may have an advantage in comparison with other ternary materials like $\mathrm{CuIn}_{2 \mathrm{n}+1} \mathrm{Se}_{3 \mathrm{n}+2}$ and $\mathrm{CuGa}_{2 \mathrm{n}+1} \mathrm{~S}_{3 \mathrm{n}+2}$. They belong to I- $\mathrm{III}_{2 \mathrm{n}+1}-\mathrm{VI}_{3 \mathrm{n}+2}$ ternary materials which are receiving a great deal of attention as candidate materials for visible-light and IR emitters, high-efficiency solar cells, and other semiconductor and quantum-electronic devices [2]. Many researchers tried to synthesize $\mathrm{CuInS}_{2}$ material by various methods because of its important properties, a new green synthesis is described by some authors without using any organic solvent [3], a new strategy has been presented to the controllable synthesis of $\mathrm{CuInS}_{2}$ hollow nanospheres based on the $\mathrm{Cu}_{2} \mathrm{O}$ solid nanospheres as the precursor in the absence of any surfactant [4], a facile and low-cost method was developed to prepare metastable wurtzite copper indium sulfide $\left(\mathrm{CuInS}_{2}\right)$ nanocrystals under atmospheric conditions [5] and luminescent $\mathrm{CuInS}_{2}$ nanocrystals were synthesized in dodecanethiol precursors [6]. $\mathrm{I}-\mathrm{III}_{2 \mathrm{n}+1}-\mathrm{VI}_{3 \mathrm{n}+2}$ ternary materials are called ordered vacancy compound (OVC). The formation of the OVC compound $\mathrm{CuIn}_{3} \mathrm{Se}_{5}$ has already been explained as due to

"Corresponding author. the presence of a single pair of the defect complex $\left(2 \mathrm{~V}_{\mathrm{Cu}}^{-1}+\operatorname{In}_{\mathrm{Cu}}^{2+}\right)$ in every five units of CIS [7]. In the present study, we have investigated the structural properties of $\mathrm{CuIn}_{2 \mathrm{n}+1} \mathrm{~S}_{3 \mathrm{n}+2}$ powders synthesized by the horizontal Bridgman method.

\section{2. $\mathrm{CuIn} 2 \mathrm{n+1} \mathrm{S}_{3 \mathrm{n}+2}$ Materials}

In order to understand the formation of ternary compounds with chemical formula $\mathrm{CuIn}_{2 n+1} \mathrm{~S}_{3 n+2}$, their phase equilibrate can be discussed in terms of temperature or composition. These compounds stabilize due to the ordering of the neutral defect pairs $\left(2 \mathrm{~V}_{\mathrm{Cu}}^{-1}+\mathrm{In}_{\mathrm{Cu}}^{2+}\right)$ in the $\mathrm{CuInS}_{2}$ phase and this is due to its huge tolerance to off-stoichiometry [8]. In our knowledge, few papers [9] dealing with the physical properties of $\mathrm{CuIn}_{2 \mathrm{n}+1} \mathrm{~S}_{3 \mathrm{n}+2}$ compounds have been reported but not much is known about the fundamental properties of this system. The ternary compositional triangle is the basis for analyzing the composition phase behavior of these materials. In Figure 1, a schematic ternary diagram for $\mathrm{CuIn}_{2 \mathrm{n}+1} \mathrm{~S}_{3 \mathrm{n}+2}$ compounds is shown. This ternary diagram can be reduced in a pseudo-binary diagram along the interconnection line between $\mathrm{Cu}_{2} \mathrm{~S}$ and $\mathrm{In}_{2} \mathrm{~S}_{3}$ binary materials. Indeed, by combining these two compounds, we can obtain all materials belonging to the family with chemical formula $\mathrm{CuIn}_{2 \mathrm{n}+1} \mathrm{~S}_{3 \mathrm{n}+2}$ with $\mathrm{n}=0,1,2,3$ and 5. The bold points along the line connecting $\mathrm{Cu}_{2} \mathrm{~S}$ and $\mathrm{In}_{2} \mathrm{~S}_{3}$ represent these materials.

\section{Synthesis of Materials}

The CuIn ${ }_{2 n+1} S_{3 n+2}$ (with $n=0,1,2,3$ and 5) crystals have 


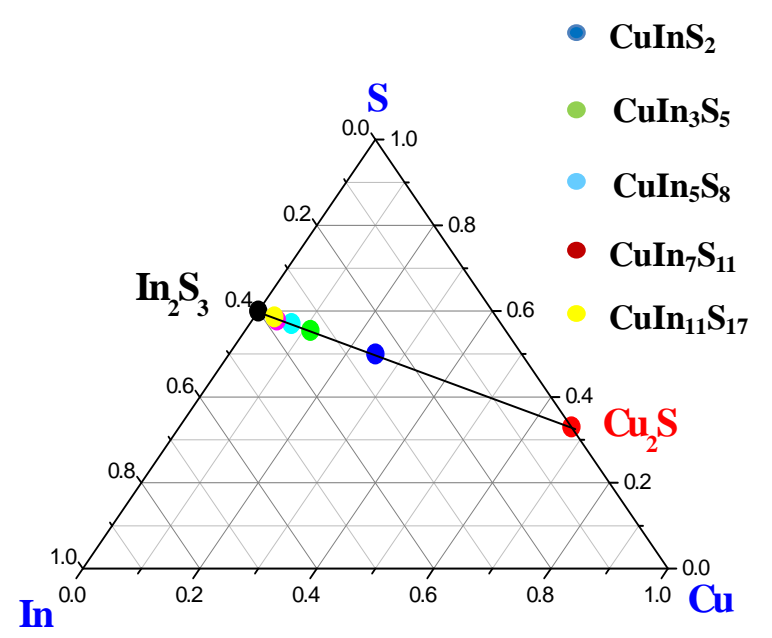

Figure 1. The ternary system $\mathrm{Cu}-\mathrm{In}-\mathrm{S}$ including the pseudo-binary section $\mathrm{Cu}_{2} \mathrm{~S}-\mathrm{In}_{2} \mathrm{~S}_{3}$.

been prepared by Bridgman horizontal method growth. High purity elemental materials of copper, indium and sulfur (Balzers 99.999\%) were taken in proportions corresponding to the stoichiometric composition of the compounds $\mathrm{CuInS}_{2}, \mathrm{CuIn}_{3} \mathrm{~S}_{5}, \mathrm{CuIn}_{5} \mathrm{~S}_{8}, \mathrm{CuIn}_{7} \mathrm{~S}_{11}$ and $\mathrm{CuIn}_{11} \mathrm{~S}_{17}$ and then loaded into five quartz ampoules. The growth of crystals was carried out in ampoules $(20 \mathrm{~cm}$ in length with thickness $2 \mathrm{~mm}$ ), that were pre-cleaned by chemical etching in concentrated acid HF, washed in distilled water then with acetone, and finally, dried in oven at $150^{\circ} \mathrm{C}$ during 30 minutes. The ampoules were evacuated down to $10^{-5} \mathrm{mbar}$ and were sealed off. The sealed ampoules containing the pure elements were placed into a horizontal position in programmable furnace (Nabertherm-Allemagne). For the synthesis, the temperature of the furnace was increased from room temperature to $600^{\circ} \mathrm{C}$ with a slow rate of $10^{\circ} \mathrm{C} /$ hour in order to avoid explosions due to sulfur vapor pressure (2 atm at $493^{\circ} \mathrm{C}$ and $10 \mathrm{~atm}$ at $640^{\circ} \mathrm{C}$ ). The temperature was kept constant at $600^{\circ} \mathrm{C}$ for 24 hours. Then, the temperature was increased with a rate of $20^{\circ} \mathrm{C}$ /hour up to $1000^{\circ} \mathrm{C}$. A complete homogenization could be obtained by keeping the melt at $1000^{\circ} \mathrm{C}$ for 48 hours. After that, the temperature was lowered to $800^{\circ} \mathrm{C}$ at a rate of $10^{\circ} \mathrm{C} /$ hour and the furnace was switched off until the tube reached room temperature. Then, the ampoules were removed from the furnace and were broken to retrieve the synthesized ingots. The resulting ingots are opaque and black in color. Figure 2 represents the $\mathrm{CuIn}_{11} \mathrm{~S}_{17}$ ingot. Finally, the $\mathrm{CuIn}_{2 \mathrm{n}+1} \mathrm{~S}_{3 \mathrm{n}+2}$ ingots were crushed in order to obtain $\mathrm{CuIn}_{2 \mathrm{n}+1} \mathrm{~S}_{3 \mathrm{n}+2}$ powders. The phases and crystallographic structure of the $\mathrm{CuIn}_{2 \mathrm{n}+1} \mathrm{~S}_{3 \mathrm{n}+2}$ powders were investigated by X-ray diffraction (XRD) using monochromatic $\mathrm{CuK}_{\alpha}$ $(\lambda=1.54052 \AA)$ radiation in $2 \theta$ range of $20^{\circ}-60^{\circ}$. The operation voltage and current used are, respectively, 40 $\mathrm{kV}$ and $30 \mathrm{~mA}$. The observed phases were determined by
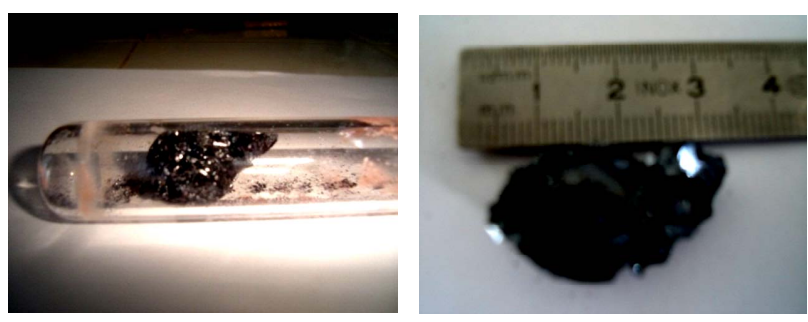

Figure 2. Photographs showing the $\mathrm{CuIn}_{11} \mathrm{~S}_{17}$ ingot.

comparing the d-spacing with Joint Committee on Powder Diffraction Standard (JCPDS) data files. The composition of powders was determined by means of energy dispersive X-ray analysis (EDX) by a JEOL $6700 \mathrm{~F}$ equipment which uses K-ray for $\mathrm{Cu}$ and L-ray for In and $\mathrm{S}$ as standards.

\section{Structural Characterization}

\subsection{XRD Results}

$\mathrm{X}$-ray diffraction $(\mathrm{XRD})$ was used to study the structural properties of $\mathrm{CuInS}_{2}, \mathrm{CuIn}_{3} \mathrm{~S}_{5}, \mathrm{CuIn}_{5} \mathrm{~S}_{8}, \mathrm{CuIn}_{7} \mathrm{~S}_{11}$ and $\mathrm{CuIn}{ }_{11} \mathrm{~S}_{17}$ powders. Figure 3 shows the $\mathrm{X}$-ray diffraction (XRD) patterns of the $\mathrm{CuIn}_{2 \mathrm{n}+1} \mathrm{~S}_{3 \mathrm{n}+2}$ materials (with $\mathrm{n}=0$, 1, 2, 3 and 5). It is clear from Figures 3(a), (b) that the peak due to the 112 plane has the highest intensity for the $\mathrm{CuInS}_{2}$ (PDF 27-0159) and $\mathrm{CuIn}_{3} \mathrm{~S}_{5}$ (PDF 35-1349) powders while the highest intensity for $\mathrm{CuIn}_{5} \mathrm{~S}_{8}$ (PDF 72-0956), $\mathrm{CuIn}_{7} \mathrm{~S}_{11}$ (PDF 49-1383) and $\mathrm{CuIn}_{11} \mathrm{~S}_{17}$ (PDF 34-0797) powders is the peak due to the 311 plane. All the diffraction peaks of the patterns shown in Figure 3 could be indexed as those of $\mathrm{CuIn}_{2 \mathrm{n}+1} \mathrm{~S}_{3 \mathrm{n}+2}(\mathrm{n}=0,1,2,3$ and 5) with tetragonal chalcopyrite structure for $\mathrm{CuInS}_{2}$ (space group $I-42 d[10]$ ) and $\mathrm{CuIn}_{3} \mathrm{~S}_{5}$ (space group $P-42 c$ [11]) and with cubic spinel structure (space group $F d 3 m$ [12-14]) for $\mathrm{CuIn}_{5} \mathrm{~S}_{8}, \mathrm{CuIn}_{7} \mathrm{~S}_{11}$ and $\mathrm{CuIn}_{11} \mathrm{~S}_{17}$. This transition in the crystal structure between $\mathrm{n}=0$ and 1 and $\mathrm{n}=$ 2, 3 and 5 in the $\mathrm{CuIn}_{2 \mathrm{n}+1} \mathrm{~S}_{3 \mathrm{n}+2}$ system can be explained by the migration of a part of $\mathrm{In}^{3+}$ ions towards octahedral sites when the indium atoms increase in the structure. Indeed, the $\operatorname{In}^{3+}$ ions can be stabilized in both tetrahedral and octahedral sites but tend to form bonding with octahedral coordinations. The spinel structure is favored by increasing the indium content in the $\mathrm{CuIn}_{2 \mathrm{n}+1} \mathrm{~S}_{3 \mathrm{n}+2}$ system [15]. We also note that the XRD patterns of all compounds do not contain extra reflections corresponding to the elements or other secondary phases, which confirms the homogeneity of the synthesized materials. The lattice parameters (a) and (c) of $\mathrm{CuInS}_{2}$ and $\mathrm{CuIn}_{3} \mathrm{~S}_{5}$ was calculated by using Equation (1) whereas Equation (2) was used to calculate the lattice parameter (a) of $\mathrm{CuIn}_{5} \mathrm{~S}_{8}$, $\mathrm{CuIn}_{7} \mathrm{~S}_{11}$ and $\mathrm{CuIn}_{11} \mathrm{~S}_{17}[16]$.

$$
\frac{1}{d^{2}}=\frac{h^{2}+k^{2}}{a^{2}}+\frac{l^{2}}{c^{2}}
$$




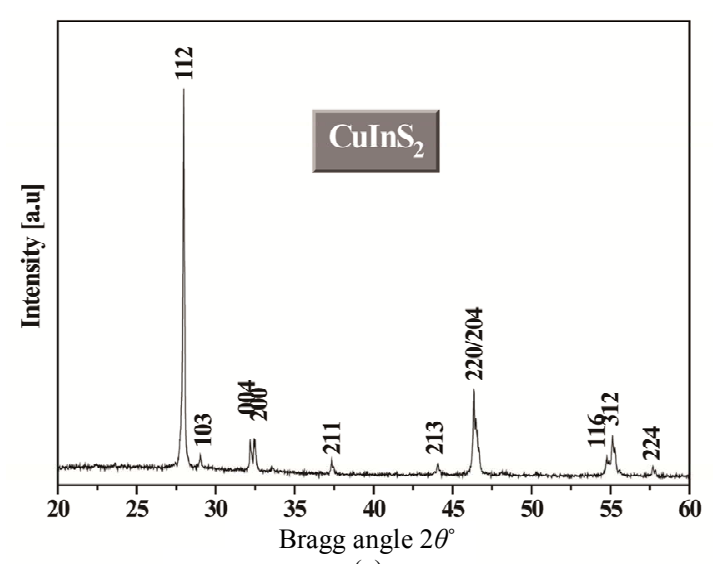

(a)

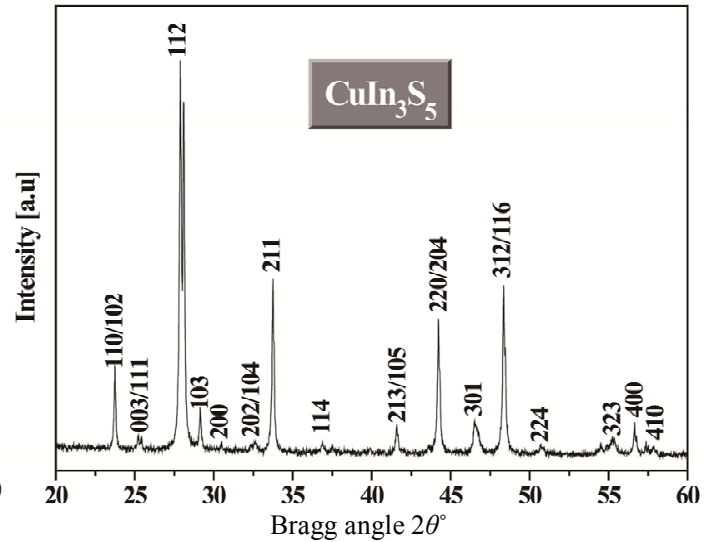

(b)

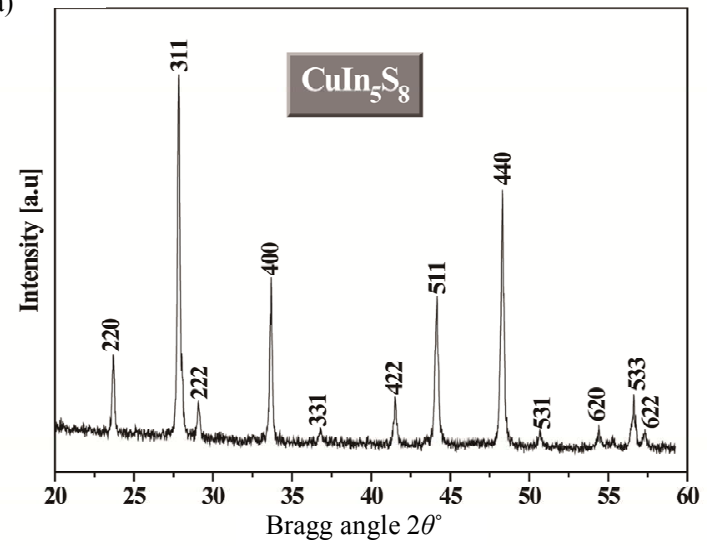

(c)

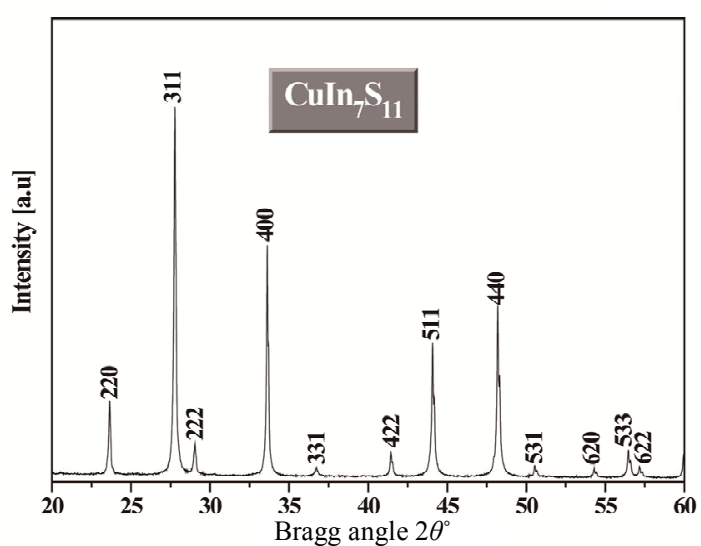

(d)

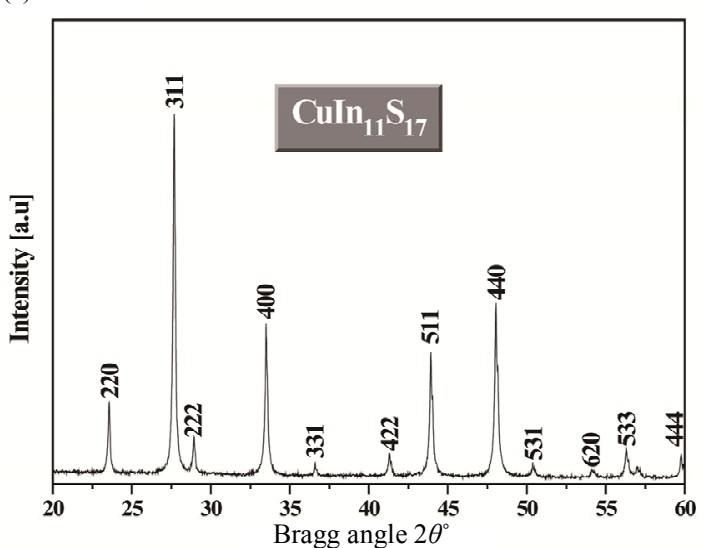

(e)

Figure 3. XRD patterns of the synthesized: (a) $\mathrm{CuInS}_{2}$ (b) $\mathrm{CuIn}_{3} \mathrm{~S}_{5}$ (c) $\mathrm{CuIn}_{5} \mathrm{~S}_{8}$ (d) $\mathrm{CuIn}_{7} \mathrm{~S}_{11}$ and (e) $\mathrm{CuIn}_{11} \mathrm{~S}_{17}$ powders.

$$
\frac{1}{d^{2}}=\frac{h^{2}+k^{2}+l^{2}}{a^{2}}
$$

where $d$ is interplanar spacing determined using Bragg's equation and $h, k, l$ are the miller indices of the lattice planes. The corrected values of lattice parameters are estimated from Nelson-Riley [17] method. Consequently, Nelson-Riley function [18]:

$$
f(\theta)=\frac{1}{2}\left(\frac{\cos ^{2} \theta}{\sin \theta}+\frac{\cos ^{2} \theta}{\theta}\right)
$$

(where $\theta$ is Bragg angle) is calculated and the Nelson-Riley plot is represented for different reflections. In this method, the value of lattice parameter is determined by extrapolating Nelson-Riley functions to $f(\theta) \rightarrow 0$.

Figure 4 represents the Nelson-Riley plots for $\mathrm{CuInS}_{2}$ and $\mathrm{CuIn}_{7} \mathrm{~S}_{11}$ powders. The calculated values of lattice parameters were collected in Table 1.

\subsection{EDX Results}

The atomic ratios of $\mathrm{Cu}$, In and $\mathrm{S}$ elements and the 
chemical composition of the prepared powders have been determined using the energy dispersive X-ray analysis (EDX). The EDX analysis is made at several zones of the powders in order to obtain an average atomic concentration. The atomic ratios of the elements and the composition of powders are presented in Table 2. The uncertainty of the present measurements is about $5 \%$. As is seen in Table 2, the compositions of $\mathrm{CuIn}_{2 n+1} \mathrm{~S}_{3 n+2}(n=0$, $1,2,3$ and 5) powders is fairly close to the ideal theoretical values of the starting composition. We also note that all powders were deficient in sulfur.

\section{Conclusion}

In summary, $\mathrm{CuIn}_{2 \mathrm{n}+1} \mathrm{~S}_{3 \mathrm{n}+2}(\mathrm{n}=0,1,2,3$ and 5) materials were successfully synthesized using the horizontal Bridgman method. The XRD spectra of the powders indicate that the $\mathrm{CuIn}_{2 n+1} \mathrm{~S}_{3 n+2}$ powders can be formed in different structures. Indeed, for $\mathrm{n}=0$ and 1 , the powders crystallize in the chalcopyrite structure with the preferential orientation along 112 plane. On the passage to $n=2$, 3 and $5, \mathrm{CuIn}_{5} \mathrm{~S}_{8}, \mathrm{CuIn}_{7} \mathrm{~S}_{11}$ and $\mathrm{CuIn}_{11} \mathrm{~S}_{17}$ powders crystallize in the spinel structure with the preferential orientation along 311 plane. The compositions of $\mathrm{CuIn}_{2 n+1} \mathrm{~S}_{3 \mathrm{n}+2}$

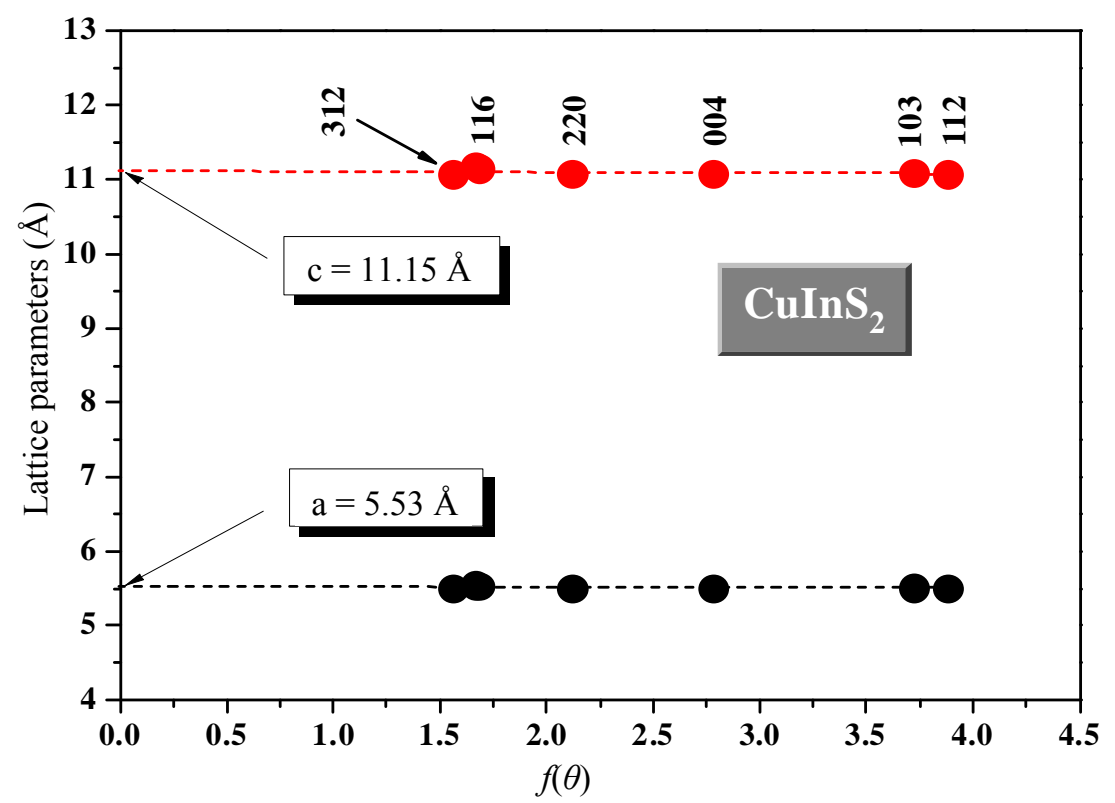

Figure 4. Nelson-Riley plots for calculation of corrected lattice parameters of $\mathrm{CuInS}_{2}$ and $\mathrm{CuIn}_{7} \mathrm{~S}_{11}$ powders.

Table 1. Lattice parameters of $\mathrm{CuIn}_{2 n+1} S_{3 n+2}(n=0,1,2,3$ and 5) powders.

\begin{tabular}{cccccc}
\hline & $\mathrm{CuInS}_{2}$ & $\mathrm{CuIn}_{3} \mathrm{~S}_{5}$ & $\mathrm{CuIn}_{5} \mathrm{~S}_{8}$ & $\mathrm{CuIn}_{7} \mathrm{~S}_{11}$ & $\mathrm{CuIn}_{11} \mathrm{~S}_{17}$ \\
\hline$a(\AA)$ & 5.53 & 5.50 & 10.47 & 10.58 & 10.70 \\
$c(\AA)$ & 11.15 & 10.85 & - & - & - \\
\hline
\end{tabular}

Table 2. Chemical compositions of $\mathrm{CuIn}_{2 n+1} \mathrm{~S}_{3 n+2}(\mathrm{n}=\mathbf{0 , 1}, 2,3$ and 5) powders.

\begin{tabular}{|c|c|c|c|c|c|c|}
\hline & & $\mathrm{CuInS}_{2}$ & $\mathrm{CuIn}_{3} \mathrm{~S}_{5}$ & $\mathrm{CuIn}_{5} \mathrm{~S}_{8}$ & $\mathrm{CuIn} \mathrm{S}_{71}$ & $\mathrm{CuIn}_{11} \mathrm{~S}_{17}$ \\
\hline \multirow{2}{*}{$\mathbf{C u}$} & Cal. & 25.00 & 11.11 & 7.14 & 5.26 & 3.44 \\
\hline & Obs. & 25.58 & 12.65 & 7.39 & 5.32 & 3.54 \\
\hline \multirow{2}{*}{ In } & Cal. & 25.00 & 33.33 & 35.71 & 36.84 & 37.93 \\
\hline & Obs. & 23.54 & 30.75 & 36.61 & 37.67 & 37.98 \\
\hline \multirow{2}{*}{$\mathrm{S}$} & Cal. & 50.00 & 55.55 & 57.14 & 57.89 & 58.62 \\
\hline & Obs. & 50.88 & 56.59 & 56.00 & 57.00 & 58.48 \\
\hline \multicolumn{2}{|c|}{ Compositions } & $\mathrm{Cu}_{1.03} \mathrm{In}_{0.93} \mathrm{~S}_{2.04}$ & $C \mathbf{u}_{1.13} I_{n_{2.78}} S_{5.09}$ & $\mathrm{Cu}_{1.03} \mathrm{In}_{5.13} \mathrm{~S}_{7.84}$ & $\mathrm{Cu}_{1.01} \mathbf{I n}_{7.15} \mathrm{~S}_{10.84}$ & $\mathbf{C} \mathbf{u}_{1.02} \mathbf{I n}_{11.01} \mathrm{~S}_{16.95}$ \\
\hline
\end{tabular}


powders were verified by EDX measurements and all powders are deficient in sulfur.

\section{REFERENCES}

[1] Y. Peña, S. Lugo, M. Calixto-Rodriguez, A. Vázquez, I. Gómez and P. Elizondo, "CuInS ${ }_{2}$ Thin Films Obtained through the Annealing of Chemically Deposited $\mathrm{In}_{2} \mathrm{~S}_{3}-\mathrm{CuS}$ Thin Films," Applied Surface Science, Vol. 257, No. 6, 2011, pp. 2193-2196. doi:10.1016/j.apsusc.2010.09.071

[2] I. V. Bodnar, "Growth, Transmission Spectra, and Thermal Expansion of $\mathrm{CuGa}_{3} \mathrm{Se}_{5}$ Single Crystals," Inorganic Materials, Vol. 44, No. 2, 2008, pp. 104-109. doi:10.1134/S0020168508020040

[3] F. Bensebaa, C. Durand and A. Aouadou, "A New Green Synthesis Method of $\mathrm{CuInS}_{2}$ and CuInSe 2 Nanoparticles and Their Integration into Thin Films," Journal of Nanoparticle Research, Vol. 12, No. 5, 2010, pp. 1897-1903. doi:10.1007/s11051-009-9752-5

[4] W. Zhang, H. Zeng, Z. Yang and Q. Wang, "New Strategy to the Controllable Synthesis of $\mathrm{CuInS}_{2}$ Hollow Nanospheres and Their Applications in Lithium Ion Batteries," Journal of Solid State Chemistry, Vol. 186, 2012, pp. 58-63. doi:10.1016/j.jssc.2011.11.042

[5] J. Guo, W. H. Zhou, M. Li, Z. L. Hou, J. Jiao, Z. J. Zhou and S. X. Wu, "Synthesis of Bullet-Like Wurtzite $\mathrm{CuInS}_{2}$ Nanocrystals under Atmospheric Conditions," Journal of Crystal Growth, Vol. 359, 2012, pp. 72-76. doi:10.1016/j.jcrysgro.2012.08.029

[6] D. Li, Y. Zou and D. Yang, "Controlled Synthesis of Luminescent $\mathrm{CuInS}_{2}$ Nanocrystals and Their Optical Properties," Journal of Luminescence, Vol. 132, No. 2, 2012, pp. 313-317. doi:10.1016/j.jlumin.2011.08.030

[7] R. R. Philip, S. Dhanya, T. N. Ashokan and B. Pradeep, "Effect of Ga Incorporation on Valence Band Splitting of OVC CuIn ${ }_{3} \mathrm{Se}_{5}$ Thin Films," Journal of Physics and Chemistry of Solids, Vol. 72, No. 4, 2011, pp. 294-29. doi:10.1016/j.jpcs.2011.01.011

[8] B. Berenguier and H. J. Lewerenz, "Efficient Solar Energy Conversion with Electrochemically Conditioned $\mathrm{CuInS}_{2}$ Thin Film Absorber Layers," Electrochemistry Communications, Vol. 8, No. 1, 2006, pp. 165-169. doi:10.1016/j.elecom.2005.08.012

[9] I. V. Bodnar, V. A. Polubok, V. Y. Rud and M. S. Serginov, "Structure Based on Silicon Compounds $\mathrm{Cu}(\mathrm{Ag}) \operatorname{In}_{\mathrm{n}} \mathrm{S}_{\mathrm{m}}$,"
Physics and Semiconductors Technique, Vol. 38, No. 2 2004, pp. 202-206.

[10] S. H. Chaki and A. Agarwal, "Growth, Surface Microtopographic and Thermal Studies of CuInS 2 ," Journal of Crystal Growth, Vol. 308, No. 1, 2007, pp. 176-179.

[11] N. Khemiri and M. Kanzari, "Comparative Study of Structural and Morphological Properties of $\mathrm{CuIn}_{3} \mathrm{~S}_{5}$ and $\mathrm{CuIn}_{7} \mathrm{~S}_{11}$ Materials," Nuclear Instruments and Methods in Physics Research B, Vol. 268, No. 3-4, 2010, pp. 268-272. doi:10.1016/j.nimb.2009.10.175

[12] A. F. Qasrawi and N. M. Gasanly, "Crystal Data, Photoconductivity and Carrier Mechanisms in $\mathrm{CuIn}_{5} \mathrm{~S}_{8}$ Single Crystals," Crystal Research and Technology, Vol. 36, No. 12, 2001, pp. 1399-1410. doi:10.1002/1521-4079(200112)36:12<1399::AID-CRAT 1399>3.0.CO;2-O

[13] F. Py, M. Womes, J. M. Durand, J. Olivier-Fourcade, J. C. Jumas, J. M. Esteva and R. C. Karnatak, "Copper in $\operatorname{In}_{2} \mathrm{~S}_{3}$ : A Study by X-Ray Diffraction, Diffuse Reflectance and X-Ray Absorption," Journal of Alloys and Compounds, Vol. 178, No. 1-2, 1992, pp. 297-304. doi:10.1016/0925-8388(92)90271-A

[14] K. Basavaswaran, T. Sugiura, Y. Ueno and H. Minoura, "Preparation of Polycrystalline $\mathrm{CuIn}_{11} \mathrm{~S}_{17}$ Semiconductor with High Crystallinity and Its Preparation of Polycrystalline CuIn ${ }_{11} \mathrm{~S}_{17}$ Semiconductor with High Crystallinity and Its Characterization," Journal of Mate- rials Science Letters, Vol. 9, No. 12, 1990, pp. 1448-1452. doi:10.1007/BF00721612

[15] N. Khemiri and M. Kanzari, "A Comparative Study of the Properties of Thermally Evaporated $\mathrm{CuIn}_{2 n+1} \mathrm{~S}_{3 \mathrm{n}+2}(\mathrm{n}=$ 0, 1, 2 and 3) Thin Films," Thin Solid Films, Vol. 519, No. 21, 2011, pp. 7201-7206. doi:10.1016/j.tsf.2010.12.212

[16] M. Ladd and R. Palmer, "Structure Determination by X-Ray Cristallography," Plenum Publishers, New York, 2003. doi:10.1007/978-1-4615-0101-5

[17] B. D. Cullity, "Elements of X-Ray Diffraction," Addison-Wesley, Boston, 1979.

[18] G. I. Rusu, P. Prepelita, R. S. Rusu, N. Apetroaie, G. Oniciuc and A. Amarie, "On the Structural and Optical Characteristics of Zinc Telluride Thin Films," Journal of Optoelectronics and Advanced Materials, Vol. 8, No. 3, pp. 922-926. 